\title{
ACRL actions, January 1989
}

\section{Highlights of the Midwinter meetings of the ACRL Board.}

$\mathbf{T}$ he Board of Directors of the Association of College and Research Libraries met twice during the ALA Midwinter Meeting in Washington, D.C.: on Sunday, January 8, 1989, and Tuesday, January 10,1989 .

\section{Awards}

The Board approved a new award proposed by the Community and Junior College Libraries Section. Two Community College Learning Resources Achievement Awards will be given annually to recognize significant achievement in the areas of program development and leadership or community service. Individuals, groups, and institutions will be eligible to receive the awards.

In a related action, the Board approved the purpose and procedures for presenting one-time awards.

The Board approved two proposals for the World Book/ALA Goal Award: 1) preparation of an ethics manual for special collections librarians, submitted by the RBMS Ethical Standards Review Committee, chaired by Beverly Lynch; and 2) a survey of scientists and engineers on the use and valuation of conference proceedings, submitted by the Science and Technology Section.

\section{Chapters}

The Board accepted the petition for chapter status for Arkansas, making it the 40th chapter affiliated with ACRL.

\section{Choice}

The Board revised the fiscal policy concerning the Choice reserve fund level. The reserve fund is now set at an amount equal to at least $50 \%$ of the average annual operating expenditures over the preceding three years.

\section{Fund-raising}

The Board approved the Planning Committee's recommendation to appoint an organizing committee to pursue the establishment of a Fundraising Discussion Group.

\section{Output measures}

The Board agreed to allocate any surplus funds over the permanent reserve available at the close of Fiscal Year 1988 to the Output Measures project. It is expected that $\$ 9,000$ will be available to be applied to the project.

\section{Outreach services}

The Board endorsed the ALA Minority Internship/Fellowship Program proposed by the ALA Office for Library Outreach Services Advisory Committee and offered to accept a headquarters intern if the project is implemented by ALA.

The Board also supported the creation of a Library Literacy Assembly, proposed by the ALA Office for Library Outreach Services. The Assembly would coordinate programming, identify concerns and gaps, and develop and promote strategies for increased literary activity within ALA.

\section{Professional liaison}

The Board approved informal liaison arrangements with the American Association for Higher Education, the Association of American Colleges, and the American Association of University Professors. As clearance is received from the ALA Committee on Organization, further liaisons will be established with associations identified by the ACRL Professional Association Liaison Committee.

\section{Programs}

The Board approved policies and procedures on 
the approval, budgeting, and planning for conference and preconference programs. They will be published in the next edition of the ACRL Guide to Policies and Procedures.

\section{Sources of revenue}

The Board endorsed the "Sources of Revenue" proposal to the H.W. Wilson Foundation for a study of academic library funding. ALA's Office of Research will conduct the study.

\section{Standards}

The Board approved a new version of the ACRL "Standards for University Libraries," which replace the 1979 edition. A draft of the standards was published in the June 1988 issue of C $b R L$ News; the finished standards will appear in the September 1989 issue. The standards are being sent to the Association of Research Libraries for endorsement and to the ALA Awards Committee for approval.

The ACRL Standards and Accreditation Committee was asked to continue its work on the definition of "standard," "guideline," and "related document," and to recommend which of these should be subject to review by the Committee, the ACRL Board, and the ALA Standards Committee.

\section{Strategic planning}

The Board recommended that strategic planning responsibilities be added to information sent to ACRL candidates and officers, and that a statement of planning responsibility be added to the general charge for committees and sections in the ALA Handbook of Organization.

\section{Teleconference on CD-ROM}

The Board agreed to co-sponsor a second teleconference on CD-ROM between the Community and Junior College Libraries Section and the Association for Educational Communications and Technology.

\section{ACRL dues increase amendment proposed}

The single most important decision the ACRL Board made at the Midwinter Meeting was to vote (unanimously) to submit to the membership a Bylaws amendment increasing the dues for personal and organizational members from $\$ 25$ to $\$ 35$ annually.

The Board members took this action because they are convinced that the programs of the Association, based as they are on the Strategic Plan, are what ACRL members want. They therefore believe it is important not to curtail the present roster of programs, but to continue revising and adding projects in line with members' wishes. (The membership survey, last completed in 1984-1985, will be carried out this year in its regular five-year cycle.)

Some excellent information on ACRL finances can be found in C $b R L$ News, December 1988, pp.757-73. Watch for a special "Letter from Three Presidents" and more information in the April issue.

\section{ACRL executive summary}

\section{Professional development}

The Rare Books and Manuscripts Section moved along on three fronts. They made plans for their one-day preconference at Annual Conference in Dallas, furthered their work on the RBMS Conference in Cambridge this September, and began activity on the 1990 preconference, which will be in Minneapolis.

All the awards committees met and selected their awardees, the most prestigious among them the Academic/Research Librarian of the Year, which will go to Northwestern University Library Director John McGowan.

The Chapters Council's Strategic Planning Committee came in with a strong report identifying continuing education as their highest priority.

With our NEH projects all coming to a conclusion, we began the work, authorized by the Executive Committee in October, of preparing a proposal for a new series, similarly designed and co-sponsored with the Public Library Association.

\section{Enhancing service capability}

The Academic Library Statistics Committee met with Art Podolsky and Larry La Moure from the National Center for Educational Statistics to discuss NCES activities and plan a strategy for more frequent data collection. Staff at ACRL and ALA worked with the College and University Personnel Association to make their salary survey results available to ACRL members, in part through $C \triangleleft R L$ News and in part upon request.

The ACRL staff answered more than 50 "advisory questions"-- long reference questions-on the topics of standards for college libraries; accreditation; collection development; planning a new library building; marketing fashion videos to academic libraries; collection development tools for business; faculty status; academic status and sanctions; lists of academic libraries; how to use academic libraries; curriculum materials centers; automation; bibliographic instruction; standards revisions; materials retention; and salaries. 